DOI https://doi.org/10.32837/app.v0i64.196

УДК 32.019.51(477)

Савон К. В. * (НУ «ОЮА»)

ORCID ID: https://orcid.org/0000-0001-5624-7262

\title{
МІЖНАРОДНИЙ ІМІДЖ УКРАЇНИ: СУЧАСНИЙ СТАН ТА ПЕРСПЕКТИВИ РОЗВИТКУ
}

\section{THE INTERNATIONAL IMAGE OF UKRAINE: CURRENT CONDITION AND PROSPECTS FOR DEVELOPMENT}

*Kateryna Savon - PhD student at the Political Theories Department, National University “Odesa Law Academy” (23, Fontanska Doroha St., Odesa, Ukraine).

\section{Abstract}

The article is devoted to the analysis of Ukraine's international image in terms of independence. The main legal provisions that regulate the process of improving the image of our country in the world have been studied. The problem that needs a solution is to raise Ukraine's prestige in the world. Some tasks have been accomplished, such as finding out the strengths and weaknesses of Ukraine's image.

A comparative method used in the article to emphasize how other countries are improving their image in the world. The article explains the differences between brand and image definitions and draws attention to the differences between the local attitude to the notion of image and international. The concept of the state's image was defined. The content of a few articles from a popular foreign mass media was analyzed for the understanding of the attitude towards Ukraine abroad. Positive and negative mentions about Ukraine were studied.

The «Ukrinform» platform was founded to translate news into different languages, but this site is not popular on the Internet. There are some actions that can improve Ukraine's image abroad, but these steps are not systematic.

The latest statistics and current position of Ukraine were analyzed in the international rankings. The legislation and work of the appropriate ministries and departments of Ukraine have been researched in terms of forming and implementation the positive image of the state with the involvement of successful international experience. 
The proposals have been made to improve such activities. This activity has been presented by the existing legislation and by own arguments. Such arguments are the increase of financing on the promotion of the positive image of Ukraine in the world, the attraction of leaders of public opinion, elimination of repetitions in legislation and concreteness in actions of responsible parties for the creation of the positive image of Ukraine.

Keywords: state image, mass media, legislation, international rankings.

Інформатизація суспільства потребує від держав, що прагнуть популяризації серед інших держав, приділити велику увагу до образу, в якому постає держава. Проблематика набуває особливого значення в умовах інформаційної війни, що ведеться Росією. В сучасних умовах політичних змін насамперед, усередині самого українського суспільства, є доцільним, поставити перед собою вирішення проблеми, як в умовах сьогодення покращити імідж нашої держави та підняти престиж України на міжнародній арені та в очах українців. В таких умовах країна завжди має дбати про свій імідж, щоб мати як внутрішню так і зовнішню підтримку своєї політики. Це стосується і iї концептуального обгрунтування, і ії практичного втілення.

Актуальність дослідження зумовлена медіатизацією політики, яка поставила на порядок денний конструювання привабливого власного іміджу, орієнтованого як на своє суспільство, активізуючи його творчий потенціал, так і на сприйняття іншими державами для розвитку ефективної співпраці. Якщо цей процес належним чином буде виконаний, то держава стане брендом, який допоможе покращити свій економічний рівень та мати важелі впливу у міжнародних відносинах.

Аналіз та пошук шляхів покращення образу України у світі та усередині держави, шляхом проектування кращого зарубіжного досвіду успішного конструювання іміджу країни, збільшення фінансування, вдосконалення правового регулювання та підвищення рівня суспільного розумінням з боку влади, бізнесу, громадськості, важливості створення позитивного іміджу України у світі сприятиме реалізації ряду конкретних теоретичних та прикладних політичних кроків, чим і визначаються елементи наукової новизни проведеного дослідження.

В епоху інформаційних важелів впливу, те, що формує образ держави, сприймається суб'єктами як правда, що формує ставлення та відношення не тільки до діяльності держави, а також і до населення 
цієї держави. Те, що про нас пишуть, є запорукою нашого успіху, чи відставання від найвпливовіших держав світу.

Питанням формування та функціонування образу України заималися такі дослідники, як М. Копійка, Т. Попова, О. Чечель, О. Щурко.

Лао-Цзи один із перших замислювався над позиціонуванням держави у світі. Можна вважати його прихильником «м'якої політики», яку можна трактувати як вплив іміджу країни на світові процеси з метою досягнення своєї мети. Джозеф Най у 1990 році ввів у науковий обіг термін «м'яка сила». «М'яка сила» дозволяє державам здійснювати свої цілі за допомогою культури, ідей та зовнішньої політики. Отже, «м'яка сила» може слугувати інструментом іміджмейкінгу.

В зарубіжній науковій думці поняття образу не існує, слово імідж $\epsilon$ англійським еквівалентом українського слова образ. Тож вітчизняні науковці часто ототожнюють поняття імідж та образ. Якщо звернутися до правового простору України, то поняття імідж $є$ узагальненим поняттям образу.

Імідж - це штучно конструйований або стихійно створений образ, що відображається у свідомості людей та виражається у їх відношенні до нього.

Успішний міжнародний імідж України для міжнародної спільноти можна назвати тоді, коли наступні фактори будуть на високих штабелях: цікавість країною, бажання в ній жити та соціальнопсихологічний настрій населення. Вплив природно-ресурсного потенціалу, внесок видатних українців у здобутки світу, структура правління, ціннісні характеристики менталітету українців, ефективність владної конструкції, соціально-психологічних настроїв населення та стабільності економіки визначаються факторами іміджу України (Чечель, 2016, с. 84).

Одним з найяскравіших чинників, які впливають на уявлення про державу, є офіційні представники політики, які запроваджують реформи та проводять їх у дію.

Імідж можна покращити за допомогою символів, що будуть ідентифікувати у свідомості людини картинку з країною, в нашій державі можна було б запропонувати такі символи як: Києво-Печерська лавра, вишиванка, рушник, корабель, борщ, вареники, Львів.

Також багато іміджмейкерів стверджують що найкращі іміджі держав були створені за допомогою широкомасштабних розва- 
жальних подій. В Україні гучними подіями залишилися Свро 2012, Євробачення, Одеський кінофестиваль, попитом користуються ярмарки у Львові, які часто організовуються присвячуючи певними цікавими для спільнот темами.

Насамперед люди, які прославляють Україну своїми виноходами, успіхами в багатьох країнах мають велику підтримку та пошану серед населення. Історії відомі приклади Андрія Шевченка, Тараса Шевченка, братів Кличко, Олександра Усика, Джамали. Проте $\epsilon$ дуже багато українців, які відомі в усьому світі, проте в нашому медіа просторі їх досягнення та прізвища звучать дуже рідко. Нещодавно українці отримали статус «Бренд-амбасадора»: Олег Іваненко, Іван Князев, Майк Кауфман-Портніков, Артемій Сурін. Боксер Василь Ломаченко, що став чемпіоном світу з боксу. Кінорежисер Євген Афінеєвський, представив документальний фільм про Майдан, що отримав номінацію на премію «Оскар». Українська художниця Анна Буччіареллі створила дизайн новорічних чашок для Starbucks. Ярослав Ажнюк потрапив до списку 100 людей-творців змін у Свропі за версією видання Financial Times. Дмитро Верьовка створив відеогру «Лісова пісня» здобула престижні нагороди. Герман Макаренко, який став першим лауреатом премії ЮНЕСКО в Україні. Американська режисера українського походження Роксі Топорович, яка виграла престижну кіно нагороду в США (Голіната, 2016).

Щодо сприйняття України у світі, то до 2013 року Україна сприймалася у світі як маловідома країна 3 неефективним керівництвом, країна видатних спортсменів, перехідна країна 3 корумпованими схемами. Ці положення підтверджували рейтинги України у різних світових індексах. Юг Мінгареллі вважає, що уявлення про Україну в Західній Європі не мають нічого спільного з реальністю (Попова, 2018).

Імідж України за думкою багатьох державних діячів інших країн жахливий, що асоціюється з війною, корупцією та скандалами.

Україні мало і в основному з негативного боку представлені новини у світі. Статті у International Herald Tribune, Wall Street Journal, Financial Times є прикладами цього.

Топовими темами 3МІ у Свропі та Північній Америці, починаючи з 2014 року були: Свробачення, міжнародне розслідування збитого Боїнгу МН17, скандал з радником Трампа. Серед позитивних були перемоги українських паралімпійців, надання Україні безвізового режиму. 
Український курс, який спрямований на Європу, має відображати цінності, які притаманні цивілізованому та розвиненому суспільству. Цікавою реакцією від Свропи було ставлення до того, які кошти мають наші політики, що вони задекларували , та що є хобі для них.

3MI, що мають вплив на англомовне середовище нашої планети, друкували інформацію, стосовно України, у таких газетах, як: АВС News, що входить в 3 найбільш поширених ЗМI США. The New York Times, яка виступає 2 в країни по числу тиражувань після The Wall Street Journal та у світі займає 39 сходинку та Reuters, англійське видавництво, що здійснює великий міжнародний вплив у питаннях новин. Слово «Ukraine» у газетах і новинних агентств найчастіше використовуються такі слова як конфлікт, війна, напад, Росія, Донецьк, рідше Крим. У заголовках телерадіомовної компанії ВВС можна частіше зустріти слово криза. Це пояснюється тим, що у bbc.com yci новини, які стосуються конфлікту на сході України публікуються під назвою українська криза.

Незважаючи на глобальні політичні трансформації і внутрішні події, сприйняття європейцями України мало в чому змінилося. Згідно з дослідженням Інституту світової політики, проведеного у 2015 року в шести найбільших країнах ЄС серед 6 тисяч осіб працездатного віку, Україну з Росією асоціює майже кожен п'ятий. Для кожного десятого Україна асоціюється з бідністю. А новим і тепер головним у цьому асоціативному ряду виявилось слово війна.

В умовах відкритого спілкування між державами постає певна конкуренція за здобуття найкращих показників. Іноді, ці показники повністю

відображують життя суспільства, і здебільшого саме через міжнародні рейтинги, спільнота бачить позитивні чи негативні зрушення у державі.

Якщо звернутися до рейтингів, що характеризують безпеку держави, то нашими сусідами за результатами є Мексика, Туніс, Габон та Сальвадор. У рейтингу Глобального індексу тероризму ми перебуваємо на 17 місці, індекс потужності армії 30 місце. Українське військо розвивається, але з дуже низького рівня, на якому воно перебувало станом на початок 2014 року.

Щодо економічних показників, то у глобальному індексу інновацій - ми знаходимося на 50 місці. Індекс процвітання 112 місце, 43 місце у рейтингу податкового навантаження. Сусідами по економічних показниках є Китай, Киргизстан, Бутан та Узбекистан. Якщо зверну184 
тися до рейтингів показників свободи, то у Глобальному рейтингу рабства Україна обіймає 25 місце на 2016 рік. У Індексі гендерного розриву - ми опинилися на 61 місці. Місце України в показниках свободи межує з Чорногорією, Гондурасом, Фіджі та Замбією.

Таким чином, якщо оцінювати іміджеві надбання та рейтингові здобутки, то слід зазначити, що підсумком буде те, що Україна значно покращила свої позиції у світі за легкістю ведення бізнесу. Після переведення багатьох податкових операцій в он-лайн режимом наша країна піднялася у веденні бізнесу на 9 пунктів, в порівнянні з 2016 роком, і зайняла 76-е місце замість 85-го. Не погані показники України в рейтингу інновацій: ми піднялися на 6 позицій і зайняли 50-е місце з 127-ми. Є цілий ряд інших позитивних зрушень на шляху позиціонування України у світі. Але в той же час українці стали менш щасливими, знизилася якість їх життя і ці показники негативно впливають на ставлення до держави, на процес формування ії позитивного образу. Отже, це потребує активних зусиль всього суспільства і влади, спрямованих на підвищення стандартів життя людей, як найвищої цінності, на основі якої і формується образ держави.

У 2002 році Україна почала запроваджувати програми щодо покращення іміджу держави. Прикладом слугує програма «Інвестиційний імідж України», основними завданнями якої полягали у систематизації знань щодо гарних нових щодо України, проведення Днів України та Днів регіонів України, проведення заходів іміджевого характеру, розроблення Інтернет - порталу «Вікно в Україну», відображення в Інтернет просторі інформації щодо державного боргу України та всі супутні данні щодо нього (Про схвалення Програми «Інвестиційний імідж України», 2002).

Також в Україні функціонує державна програма забезпечення позитивного міжнародного іміджу України з 2003 року. Основна мета полягає у підтриманні іміджу України, поліпшення чинників щодо підвищення престижу України, посиленні ефективності роботи органів виконавчої влади, які відповідають за імідж (Про затвердження «Державної програми забезпечення позитивного міжнародного іміджу України на 2003-2006 роки», 2003).

У 2008 році була розроблена державна цільова програма формування позитивного міжнародного іміджу України на 2008-2011 роки, основними завданнями якої було: інформація щодо інших держав та спрямованості їхнього населення, проведення інформаційної акції з населенням України для розуміння якого стратегічного курсу 
треба дотримуватися, встановлення зв'язків 3 міжнародними організаціями та неурядовими організації, для покращення свого іміджу, сприянню збільшенню позитивного сегменту про Україну в іноземних 3MI. На нашу думку, такі завдання є актуальними і на сьогоднішній день в умовах негативного сприйняття України у світі. На сьогоднішній день програма не була виконана у повному обсязі та потребує реалізації (Про схвалення Концепції «Державної цільової програми формування позитивного міжнародного іміджу України на 2008-2011 роки», 2007).

Постановою від 3 червня 2009 року була затверджена державна цільова програма формування позитивного міжнародного іміджу на період до 2011 року. На даний час це єдине офіційне джерело, у якому представлений обсяг державних коштів, які спрямовані на покращення образу України у світі. Цей документ діє сьогодні і його виконання досі здійснюється. 3 урахуванням державного бюджету та місцевого фінансування іміджевої галузі України було приблизно 10000\$ у рік (Про схвалення Концепції «Державної цільової програми формування позитивного міжнародного іміджу України на 2008-2011 роки», 2007). Найновішими пропозиціями були: залучення закордонних іміджмейкерів, навчання та підвищення кваліфікації людей, які займаються іміджем України, налагодження співпраці держадміністрації з громадськими організаціями, які займаються покращенням іміджу України, проведення соціологічних опитувань серед громадян зарубіжних країн для визначення ставлення до України.

Серед медіа здобутків України можна перерахувати розміщення каналу UATV - Іномовлення України в YouTube, що транслюється з українською, російською, кримськотатарською, англійською мовами. Проте обсяг аккаунтів, що підписані на цей канал лише 10000 користувачів. Провідні країни як: США, Англія, Німеччина, Франція, Китай, Японія витрачають величезні кошти на ведення 3МІ різними мовами, підготовку якісного та цікавого контенту, освітлення подій у всьому світі. Наукові та освітні установи цих держав залучають до співпраці найкращих спеціалістів світу для удосконалення свого міжнародного образу та формування поваги зі сторони міжнародної спільноти. Україна ж робить лише перші кроки на цьому шляху, але при цьому маючи можливість залучати кращий світовий досвід. Результати таких зусиль будуть залежати від багатьох факторів: зокрема, ми маємо чітко розуміти зміст самих понять, що використовуються в процесі формування образу держави. Також теоретичні 
пошуки повинні визначати практичні дії по створенню і впровадженню позитивного образу України. Позитивним зрушенням на цьому шляху є усвідомлення необхідності покращення образу нашої держави у світі, що відображається у «Стратегії України 2020» (Про Стратегію сталого розвитку «Україна - 2020», 2015). Цей документ закладає теоретичну платформу дій по впровадженню позитивного образу України, сприяє вдосконаленню необхідної нормативної бази.

Важливим досягненням інституційного характеру є створення у 2014 році Міністерства інформаційної політики для забезпечення інформаційного суверенітету України. За допомогою Міністерства почалася популяризація української мови, українського кінематографу, популяризація України у світі. МІП України також затвердило бренд Ukraine Now, який стане основою презентації України у світі.

Також створений сайт «Укрінформ», на якому можна почитати новини українською, російською, англійською, іспанською, німецькою, польською, французькою та китайською мовами. Укрінформ інформаційне агентство України. Кореспонденти агентства працюють по всій України та в провідних країнах світу, де розвинута українська діаспора. 2018 року ролики з просування інтересів України у світі випускались в ефір CNN. У 2018 році забезпечено поширення відеороликів «Україна - це Свропа» на міжнародному телеканалі Euronews (Міністерство інформаційної політики України. БРЕНД ТА ПОПУЛЯРИЗАЦІЯ, 2018).

Загальнонаукові аргументи вирішення поставленої проблеми відображаються у правовому просторі України, основними позиціями якого є:

- «Покращення міжнародних комунікацій;

- Зрощування зусиль бізнесу з органами державної влади у вирішенні позиціонування України як держави - лідера;

- Формування і просування бренд-меседжів про Україну;

- Збільшення присутності українців у міжнародних заходах;

- Формування сталих ефективних комунікацій з українською діаспорою за кордоном;

- Регулярний відкритий діалог з спільнотою через світових лідерів думок» (Про затвердження «Порядку використання коштів, передбачених у державному бюджеті для фінансової підтримки забезпечення міжнародного позитивного іміджу України, забезпечення діяльності Українського інституту та здійснення заходів щодо підтримки зв' язків з українцями, які проживають за межами України», 2017). 
Авторські аргументи вирішення поставленої проблеми:

- Фінансове збільшення бюджетних коштів на покращення образу України у світі на прикладі ОАЕ, які одну шосту бюджету країни витрачають на конструювання іміджу;

- Просування у світі позитивного контексту про Україну: збільшення ведення 3МІ англійською та російською мовою, а краще і іншими мовами (приклад Росія); створення, просування та можливість користування каналів комунікацій за кордоном;

- Закінчити війну на сході нашої держави та покращити економічні показники, особливою ланкою є збільшення «середнього класу», як ключовий вектор входження до європейської інтеграції, 3 моєї точки зору;

- Скоротити та уточнити неактуальність у національно-правових засадах, що регулюють питання образу України;

- Звернути увагу в Міністерствах, в компетенція яких є покращення нашого образу, на досвід Німеччини, як можна підняти національний патріотизм за допомогою акцентування уваги на великих досягнень зроблених німцями; залучати лідерів світових думок до презентації нашої держави, на прикладі плакатів з Клаудією Шиффер.

Тож міжнародний імідж України носить подвійний характер. 3 одного боку, на сьогоднішній день Україна сприймається у світі як держава, що поступово утверджується як демократична, європейська та незалежна. Ці аспекти можна характеризувати як елементи позитивного образу країни демократичного транзиту. Разом з тим, існують і елементи негативного образу. Наразі це єдина держава у Свропі, у якій ведуться воєнні дії, країна з нечітко визначеною та не прийнятною для частини суспільства національною ідеєю, країна з високим рівнем бідності населення та іноді незрозумілими та застарілими для європейців цінностями у представників політичної еліти.

Висновок полягає у тому, що покращення іміджу нашої держави та підняття престижу України на міжнародній арені та в очах українців залежить не тільки від держави, а і від пересічного громадянина, який вважає Україну - «Країною мрій», чи «Країну з війною та повною корупцією». Акцентування уваги українців, особливо журналістів, який меседж ми відправляємо у світ і як це може вплинути на імідж України є ключовим питанням. 


\section{Лiтература:}

Голіната, А. (2016). 10 українців, які змусили світ говорити про Україну в 2016 році. Радіо Америки. URL: https://ukrainian.voanews.com/a/ desiat-ukraintsiv-proslavyly-ukrainu-2016/3654654.html.

Копійка, М. (2017). Особливості формування іміджу України в міжнародному інформаційному просторі. Гілея: історичні науки, філософські науки, політичні науки, Вип. 124 (№9), 266-269.

Міністерство інформаційної політики України. БРЕНД ТА ПОПУЛЯРИЗАЦЯ (2018). Офіиійний сайт Міністерства інформаційної політики України. URL: https:/ / mip.gov.ua/content/askyourquestion.html

Попова, Т. (2018). Наш імідж. Як Україну сприймають у світі. НВ журнал. URL: https:/ / nv.ua/ukr/opinion/nash-imidzh-jak-ukrajinusprijmajut-u-sviti-2459084.html.

Про затвердження "Державної програми забезпечення позитивного міжнародного іміджу України на 2003-2006 роки»: Постанова Кабінету Міністрів України від 15. 10.2003 № 1609 (Кабінет Міністрів України). Компания ЛИГА_ЗАКОН. URL: http:/ / search.ligazakon.ua/1_doc2.nsf/ link1/KP031609.html

Про затвердження «Порядку використання коштів, передбачених у державному бюджеті для фінансової підтримки забезпечення міжнародного позитивного іміджу України, забезпечення діяльості Українського інституту та здійснення заходів щодо підтримки з 'язків з украӥниями, які проживають за межами України»: Постанова Кабінету Міністрів України від 22.03.2017 № 165 (Кабінет Міністрів України). Офіиіиіний сайт Верховної Ради України. URL: https://zakon.rada.gov.ua/laws/ show/165-2017-п

Про Стратегію сталого розвитку «Україна - 2020»: Указ Президента України від 12.01.2015 № 5/2015 (Президент України). Офічійний сайт Верховної Ради України. URL: https://zakon5.rada.gov.ua/laws/ show/5/2015

Про схвалення Кониепиї «Державної иільової програми формування позитивного міжнародного іміджу України на 2008-2011 роки»: Розпорядження Кабінету Міністрів України від 06.06.2007 № 379-р (Кабінет Міністрів України). Офіиійний сайт Верховної Ради України. URL: https:/ / zakon.rada.gov.ua/laws/show/379-2007-p

Про схвалення Програми «Інвестиційний імідж Украӥни»: Розпорядження Кабінету Міністрів України від 17.08.2002 № 477-р (Кабінет Міністрів 
України). Офіиійний сайт Верховної Ради України. URL: https:/ / zakon. rada.gov.ua/laws/show/477-2002-p

Чечель, О. Ю. (2016). Формування іміджу держави на міжнародній арені. Інвестииї: практика та досвід, 10 (травень), 82-86.

Щурко, О. (2007). Чинники формування міжнародного образу держави: принципи класифікації. Політична наука $b$ України: стан $i$ перспективи. URL: http:/ / postua.info/shchurko.htm.

Duregger, B. (2017). Similar but not equal: the image of Ukraine on Russian news websites by Boris Duregger. Raam op Rusland. URL: https:// raamoprusland.nl/studenten/scripties/862-similar-butnot-equal-the-image-of-ukraine-on-russian-news-websites.

Internet Top 20 Countries (2017). Miniwatts Marketing Group. URL: https:/ / www.internetworldstats.com/top20.htm.

Olena, T. (2018). Ukraine in World Media Content: Problematic and Thematic Aspects. Global Media Journal. URL: http:/ / www.globalmediajournal.com/ open-access/ukraine-in-world-media-content-problematic-and-thematicaspects.php?aid $=86827$.

Prentice, A. (2016). Ukrainians shocked as politicians declare vast wealth. Reuters. URL: https://www.reuters.com/article/us-ukraine-crisiscorruption/ukrainians-shocked-as-politicians-declare-vast-wealthidUSKBN12V1EN

\section{References:}

Chechel', O. Yu. (2016). Formuvannya imidzhu derzhavy na mizhnarodniy arena [Formation of the state image in the international arena]. Investytsiyi: praktyka ta dosvid [Investments: Practice and Experience], 10 (traven'), 82-86. [in Ukrainian].

Duregger, B. (2017). Similar but not equal: the image of Ukraine on Russian news websites by Boris Duregger. Raam op Rusland. URL: https:/ / raamoprusland.nl/studenten/scripties/862-similar-butnot-equal-the-image-of-ukraine-on-russian-news-websites.

Holinata, A. (2016). 10 ukrayintsiv, yaki zmusyly svit hovoryty pro Ukrayinu v 2016 rotsi [Ukrainians who made the world talk about Ukraine in 2016]. Radio Ameryky [Radio America]. URL: https:/ / ukrainian.voanews.com/a/ desiat-ukraintsiv-proslavyly-ukrainu-2016/3654654.html. [in Ukrainian]. Internet Top 20 Countries (2017). Miniwatts Marketing Group. URL: https:/ / www.internetworldstats.com/top20.htm. 
Kopiyka, M. (2017). Osoblyvosti formuvannya imidzhu Ukrayiny $\mathrm{v}$ mizhnarodnomu informatsiynomu prostori [Features of formation of the image of Ukraine in the international information space]. Hileya: istorychni nauky, filosofs'ki nauky, politychni nauky [Gilea: historical sciences, philosophical sciences, political sciences], Vyp. 124 (\#9), 266-269. [in Ukrainian].

Ministerstvo informatsiynoyi polityky Ukrayiny. BREND TA POPULYaRYZATsIYa (2018) [Ministry of Information Policy of Ukraine. BRAND AND POPULARIZATION (2018)]. Ofitsiynyy sayt Ministerstva informatsiynoyi polityky Ukrayiny [Official site of the Ministry of Information Policy of Ukraine]. URL: https://mip.gov.ua/content/askyourquestion. html. [in Ukrainian].

Olena, T. (2018). Ukraine in World Media Content: Problematic and Thematic Aspects. Global Media Journal. URL: http:/ / www.globalmediajournal.com/ open-access / ukraine-in-world-media-content-problematic-and-thematicaspects.php? aid $=86827$.

Popova, T. (2018). Nash imidzh. Yak Ukrayinu spryymayut' u sviti [Our image. How Ukraine is perceived in the world]. NV zhurnal [HB magazine]. URL: https://nv.ua/ukr/opinion/nash-imidzh-jak-ukrajinu-sprijmajutu-sviti-2459084.html. [in Ukrainian].

Prentice, A. (2016). Ukrainians shocked as politicians declare vast wealth. Reuters. URL: https://www.reuters.com/article/us-ukraine-crisiscorruption/ ukrainians-shocked-as-politicians-declare-vast-wealthidUSKBN12V1EN

Pro skhvalennya Kontseptsiyi «Derzhavnoyi tsil'ovoyi prohramy formuvannya pozytyonoho mizhnarodnoho imidzhu Ukrayiny na 2008-2011 roky»: Rozporyadzhennya Kabinetu Ministriv Ukrayiny vid 06.06.2007 \# 379-r [On approval of the Concept of the State Target Program for Formation of a Positive International Image of Ukraine for 2008-2011: Order of the Cabinet of Ministers of Ukraine of 06.06.2007 No. 379-p] (Kabinet Ministriv Ukrayiny). Ofitsiynyy sayt Verkhovnoyi Rady Ukrayiny [Official site of the Verkhovna Rada of Ukraine]. URL: https://zakon.rada.gov.ua/laws/ show/379-2007-r. [in Ukrainian].

Pro skhvalennya Prohramy "Investytsiynyy imidzh Ukrayiny»: Rozporyadzhennya Kabinetu Ministriv Ukrayiny vid 17.08.2002 \# 477-r [On approval of the Program "Investment Image of Ukraine": Order of the Cabinet of Ministers of Ukraine dated August 17, 2002 \# 477-r] (Kabinet 
Ministriv Ukrayiny). Ofitsiynyy sayt Verkhovnoyi Rady Ukrayiny [Official site of the Verkhovna Rada of Ukraine]. URL: https:/ / zakon.rada.gov. ua/laws/show/477-2002-r. [in Ukrainian].

Pro Stratehiyu staloho rozvytku «Ukrayina - 2020»: Ukaz Prezydenta Ukrayiny vid 12.01.2015 \# 5/2015 [On the Sustainable Development Strategy "Ukraine 2020": Presidential Decree No. 5/2015 of 12.01.2015] (Prezydent Ukrayiny). Ofitsiynyy sayt Verkhovnoyi Rady Ukrayiny [Official site of the Verkhovna Rada of Ukraine]. URL: https://zakon5.rada.gov.ua/laws/ show/5/2015. [in Ukrainian].

Pro zatverdzhennya «Derzhavnoyi prohramy zabezpechennya pozytyonoho mizhnarodnoho imidzhu Ukrayiny na 2003-2006 roky»: Postanova Kabinetu Ministriv Ukrayiny vid 15. 10.2003 \# 1609 [On approval of the State Program for Ensuring a Positive International Image of Ukraine for 20032006: Resolution of the Cabinet of Ministers of Ukraine dated 15.10.2003 No. 1609] (Kabinet Ministriv Ukrayiny). Kompanyya LYHA_ZAKON [Company LIGA_LAW]. URL: http://search.ligazakon.ua/1_doc2.nsf/ link1/KP031609.html. [in Ukrainian].

Pro zatverdzhennya «Poryadku vykorystannya koshtiv, peredbachenykh $u$ derzhavnomu byudzheti dlya finansovoyi pidtrymky zabezpechennya mizhnarodnoho pozytyonoho imidzhu Ukrayiny, zabezpechennya diyal'nosti Ukrayins'koho instytutu ta zdiysnennya zakhodiv shchodo pidtrymky zv"yazkiv $z$ ukrayintsyamy, yaki prozhyvayut' za mezhamy Ukrayiny»: Postanova Kabinetu Ministriv Ukrayiny vid 22.03.2017 \# 165 [On Approving the Procedure of Using the Funds Provided in the State Budget for Financial Support of Ensuring the International Positive Image of Ukraine, Ensuring the Activity of the Ukrainian Institute and Implementing Measures to Support Relations with Ukrainians Living outside Ukraine: Resolution of the Cabinet of Ministers of Ukraine dated 22.03.2017 No. 165] (Kabinet Ministriv Ukrayiny). Ofitsiynyy sayt Verkhoonoyi Rady Ukrayiny [Official site of the Verkhovna Rada of Ukraine]. URL: https://zakon.rada.gov. ua/laws/show/165-2017-p. [in Ukrainian].

Shchurko, O. (2007). Chynnyky formuvannya mizhnarodnoho obrazu derzhavy: pryntsypy klasyfikatsiyi [Factors of formation of the international image of the state: principles of classification]. Politychna nauka v Ukrayiny: stan $i$ perspektyoy [Political Science in Ukraine: Status and Prospects]. URL: http://postua.info/shchurko.htm. [in Ukrainian]. 


\section{Анотація}

Савон К. В. Міжнародний імідж Украӥни: сучасний стан та перспективи розвитку. - Стаття.

Стаття присвячена аналізу міжнародного іміджу України в умовах набуття незалежності. Вивчено основні правові положення, що регулюють процес покращення міжнародного іміджу України у світі та всередині держави.. Проблема, яка потребує вирішення, полягає у підвищенні престижу України у світі. Серед поставлених завдань, були виконані такі, як з'ясування сильних та слабких сторін іміджу України.

У статті використовується порівняльний метод для того, щоб підкреслити, як інші країни покрашують свій державний імідж у світі. У статті пояснюються відмінності між визначеннями бренду та іміджу. Акцентується увага на різниці між вітчизняним відношенням до поняття іміджу та міжнародним. Було дано визначенням поняттю іміджу країни. Для розуміння ставлення до України за кордоном було проаналізовано зміст кількох статей популярних закордонних ЗМІ. Були вивчені позитивні та негативні згадки про Украӥну.

Платформа «Укрінформ» була створена для перекладу новин на різні мови, але цей сайт не користується популярністю в Інтернеті. $€$ певні кроки, що покращують імідж України за кордоном, але ціі кроки не є систематичними.

Останні статистичні дані та поточна позиція України у міжнародних рейтингах були проаналізовані. Досліджено законодавство та роботу відповідних міністерств та відомств України щодо формування та впровадження позитивного іміджу держави із залученням успішного міжнародного досbidy y cbimi.

Були зроблені пропозицї щодо вдосконалення такої діяльності. Ця діяльність була представлена чинним законодавством та власними аргументами. Такими аргументами виступають: збільшення фінансування на просування позитивного іміджу України у світі, залучення лідерів світових думок, усунення повторів у законодавстві та конкретність у діях відповідальних сторін за створення позитивного іміджу України.

Ключові слова: імідж держави, ЗМI, законодавство, міжнародні рейтинги. 